NBER WORKING PAPER SERIES

U.S. ANTIDUMPING POLICIES:

THE CASE OF STEEL

Barry J. Eichengreen

Hans van der Ven

Working Paper No. 1098

NATIONAL BUREAU OF ECONOMIC RESEARCH

1050 Massachusetts Avenue

Cambridge MA 02138

March 1983

Prepared for the NBER Conference on the Structure and Evolution of U.S. Trade Policies. We are indebted to Susan Houseman for exceptionally capable research assistance, and to Barbara Sloan of the European Community Information Service for help with the statistics. We are grateful to Alan Auerbach, Richard Caves, Wesley Cohen, Gene Grossman, Elhanan Helpman, Joseph Kalt, Hans Mueller, Joel Mokyr, Barbara Spencer, Peter Suchman, and Lars Svensson for comments. We thank also our Conference discussants, William Ethier and Gary Horlich, for their helpful remarks. Eichengreen's research draws on work supported by the Social Science Research Council. Van der Ven's research was made possible by a Paul Henry Spaak Fellowship through the Harvard Center for International Affairs. The views expressed and any errors that remain are the author's alone and should not be attributed to any above-mentioned individuals or organizations. The research reported here is part of the NBER's research program in International Studies and project in Productivity in the World Economy. 


\title{
U.S. Antidumping Policies: The Case of Steel
}

\begin{abstract}
This paper examines the controversy surrounding recent allegations that foreign producers are dumping steel products onto U.S. markets. The paper is in four sections, which take four quite distinct views of dumping and recent U.S. antidumping policies, emphasizing the changing definition of dumping and the development of administrative procedures. Section II focuses on the application of these procedures to the international steel trade, taking as a case study the most noteworthy of recent innovations: the Trigger Price Mechanism for steel. Section III considers models that can be used to analyze dumping. The models of most relevance to the practices currently at issue in the steel industry seem to us models of oligopolistic rivalry in imperfectly competitive, segmented markets. We develop a model designed to identify crucial factors upon which the incidence of dumping will depend: the number of firms producing for each national market, their costs, their market shares, and the extent to which they recognize and exploit their mutual dependence. Finally, in Section IV we calibrate these models to illustrate how the extent of dumping and the effects of the TPM depend on the model's parameters.
\end{abstract}

Barry J. Eichengreen

National Bureau of Economic Research 1050 Massachusetts Avenue

Cambridge, MA 02138

(617) 868-3983

\author{
Hans van der Ven \\ Harvard Business School \\ 300 Morgan $\mathrm{Hall}$ \\ Boston, MA 02163
}


Few aspects of international economic relations are as contentious as the allegation of dumping and the enforcement of antidumping statutes.

Recently, attention has been focused on allegations by U.S. producers of foreign violations of U.S. trade law, most notably in the steel sector. The controversy surrounding these allegations clearly has focused the attention of foreign governments, which have threatened to retaliate against the United States if antidumping duties are assessed. To defuse a potentially explosive situation, the U.S. has experimented with a new form of administered protection, the Trigger Price Mechanism for steel, and made several formal and informal attempts to negotiate orderly marketing arrangements with foreign governments and producers.

Dumping complaints certainly are not limited to steel. Indeed, recent allegations are notable for their catholicity: in the U.S. alone, dumping complaints have ranged from trade in basic agricultural commodities to sophisticated high technology products, encompassing exports from developed and developing countries alike. Neither are dumping allegations new; by now such complaints have been prevalent in the international steel trade for more than a century. However, not since the 1920s, in the environment of mutual suspicion and costly structural adjustment that followed the First World War, have these allegations been so widespread. Indeed, dumping complaints and the use of antidumping policies to protect industries claiming injury from "unfair competition" are prototypical of the "new protectionism" of the post-Bretton Woods era. In contrast to the operation of traditional trade restrictions, which typically entails the imposition of specific or ad valorem tariffs at well-defined rates or quotas at well-defined levels, the new protectionism is characterized by trade restrictions administered on a contingent basis by complex bureaucracies 
exercising a considerable degree of discretion. Antidumping duties generally, and the Trigger Price Mechanism in particular, can be seen as instances of this phenomenon.

In part, recent interest in U.S. antidumping policy has been stimulated by changes in the popular connotation attached to the term "dumping." Under the provisions of the U.S. Antidumping Act of 1921, the primary definition of dumping was export sales at a price below that of sales in the home market. Following Viner (1923), economists generally adhered to this criterion, defining dumping as price discrimination between national markets and explaining it with familiar theories of monopolistic behavior. This definition encompasses both the standard case of export prices below domestic prices and the opposite configuration, known as "reverse dumping." However, the 1921 Antidumping Act also included a provision to be invoked in the absence of comparable sales in foreign markets. In such instances, dumping was said to occur when export prices failed to cover a statutory measure of foreign producers' production costs. Nearly half a century ago, Haberler (1937) noted that this "rival" definition had gained considerable currency. The 1974 U.S. Trade Act and 1979 Trade Agreements Act further broadened the applicability of these constructed value provisions. As dumping allegations increasingly have come to revolve around the relation of prices to production costs, the literature has extended beyond reasons for price discrimination to encompass also the motivation for sales at prices that fail to cover costs (e.g., Ethier [1982]; Davies and McGuinness $[1982])$.

In this paper, we analyze dumping from both theoretical and empirical viewpoints.1 The paper is in four sections, which take four quite distinct views of dumping and recent U.S. antidumping policies. Section I describes the 
evolution of U.S. antidumping policies, emphasizing the changing definition of dumping and the development of administrative procedures. Section II focuses on the application of these procedures to the international steel trade, taking as a case study the most noteworthy of recent innovations: the Trigger Price Mechanism (TPM). We analyze the administrative and procedural conventions that caused the TPM to be attractive in the first place but contributed ultimately to its demise, and we examine its economic effects. Given recent events, this analysis has the appearance of an extended postmortem, but we think it serves an important function in illuminating some general principles about the effects of administered protection.

Section III formulates a model that can be used to analyze dumping. We discuss both the "traditional" definition of dumping as price discrimination among national markets and the "modern" definition of dumping as pricing below costs. Evidence presented below indicates the presence of substantial price discrimination persisting for extended periods in markets for steel products such as cold rolled sheet and concrete reinforcing bars. For this and other reasons, in our theoretical and empirical analyses, we concentrate on the traditional definition of dumping as price discrimination in international trade. Section IV of the paper calibrates the model and uses it to illustrate how the extent of dumping and the TPM's effects depend on the model's parameters. The final section presents some concluding remarks.

\section{The Evolution of U.S. Antidumping Policies}

Current U.S. antidumping statutes can be traced to the Antidumping Act of 1921.2 The avowed purpose of the 1921 Act was to deter predatory pricing in international trade in order to prevent foreign monopolization of domestic markets.3 Its provisions, as incorporated into the 1930 Tariff, remained little 
changed until the $1950^{\prime} \mathrm{s}$. The Secretary of the Treasury was to investigate dumping complaints by comparing U.S. import prices with the "fair value" of imports. Upon finding that fair value exceeded U.S. import prices, Treasury was to calculate the difference, known as the dumping margin, and finding evidence of material injury to U.S. producers to assess an antidumping duty. Measurement of U.S. import prices was straightforward: the FOB factory sales price could be used except when the transaction between foreign supplier and U.S. purchaser was not at arm's length, in which case U.S. market price, net of import charges and costs of transportation and preparation for the market, could be substituted. From the law's inception, the calculation of fair value was ambiguous, since the concept was not defined by statute. From 1921 through 1954, Treasury used as a standard for fair value a commodity's foreign market value or, in its absence, constructed value. Foreign market value was a transactions price, preferably observed in the exporter's home market but otherwise in third markets. Constructed value was a complex measure made up of allowances for production costs, costs of preparing the good for shipment, and statutory minima for general expenses and profits.

Before 1955, Treasury calculations of fair value and foreign market value rarely proved problematic. Most dumping cases simply were disposed of on the grounds that injury was absent or on the acceptance of price assurances. In 1954, however, an amendment to the Antidumping Act assigned responsibility for determining injury to the Tariff Commission and instructed that injury decisions be deferred pending the Treasury ruling that dumping was present, thereby subjecting the Treasury decision to public scrutiny. In addition, the growth of trade with centrally-planned economies for which market prices were not readily observed increased Treasury's reliance on constructed value. Repeatedly, 
Treasury was forced to revise its procedures as new complications arose. On several occasions between 1958 and 1974, antidumping regulations were modified to bring them into conformance with established practice.

The amendments to the Antidumping Act contained in the Trade Act of 1974 culminated this process of revision. Of greatest consequence was Section 205(b), which defined new circumstances under which the constructed value criterion could be substituted for foreign market value.4 In instances where ales "over an extended period of time and in substantial quantities" we re made in the foreign producer's home market at prices below costs of production, those foreign market prices were to be disregarded and constructed value calculations were to be substituted. Despite ambiguity about the meaning of "an extended period" and "substantial quantities," this revision of the law represented a significant shift in the design of U.S. antidumping policies from an emphasis on dumping as price discrimination to an emphasis on dumping as sales below cost.

The economic effects of the constructed value provisions in U.S. antidumping statutes have been the subject of considerable recent discussion. 5 According to U.S. antidumping law, constructed value should be a guide to prices which permit the recovery of raw material and fabrication costs, plus a ten per cent minimum allowance for general expenses and an eight per cent minimum allowance for profits. 6 other than the "extended period" clause, the Act makes no provision for the profit margin to vary over the business cycle. Thus, the law makes it difficult for firms to cut prices when market conditions are unfavorable and increases the likelihood that marginal cost pricing during recessions will be construed as dumping. Moreover, the eight per cent profit allowance, which makes no provision for variations in corporate finance, 
requires a higher return on equity for firms with higher debt-equity ratios, and the ten per cent allowance for general expenses makes no provision for variations in cost structure.

These provisions provided a considerable incentive for U.S. producers to file antidumping suits. In the case of the steel industry, other factors also contributed to the growing incidence of dumping complaints. The United States had been a net importer of steel products since 1959, and by 1968 the import share of the U.S. market had risen to nearly 17 per cent. In 1969 the first of two successive voluntary restraint agreements with the European Community and Japan went into effect. When the second of these agreements expired in 1974, coincident with the end of the 1972-74 steel market boom, U.S. producers pressed with growing vigor for further voluntary restraints, but without success.7 From 1975 through 1977, the industry's position worsened: three consecutive years of exceptionally low shipments by domestic producers culminated in a serious profit squeeze. In 1977, the Carter Administration suggested that the U.S. steel industry drop its campaign for quantitative import restrictions in return for strict enforcement of the provisions of the 1974 Trade Act providing protection from unfair foreign competition. As the proceedings of the Gilmore case, filed in early 1977, seemed to indicate, this approach was highly promising. When the industry initiated 23 dumping complaints, the European Community threatened to retaliate against the U.S., while Treasury and the ITC were confronted by the difficulty of processing the petitions within required time limits.

The Administration had already established a Treasury task force to study the problem. Its recommendations included a reference price system to facilitate rapid initiation of steel dumping complaints. 8 In the event that 
steel was imported at a price below reference prices based upon the constructed value of Japanese steel (Japan being assumed the world's most efficient producer), a Treasury dumping investigation automatically would be triggered. Hence the term "Trigger Price Mechanism." Claiming insufficient resources both to administer the TPM and to investigate independent dumping complaints, Treasury warned the industry that the TPM would be maintained only so long as producers refrained from filing antidumping petitions. Eventually, the steel industry complied and withdrew most of its complaints.

The Trade Agreements Act of 1979 represented an attempt to limit the discretion of administrative authorities, to enhance the prospect of relief for petitioners, and to strengthen opportunities for judicial review. Title I of the 1979 Act replaced the Antidumping Act of 1921. Its central provisions shortened the time limits within which an antidumping determination must be reached. Under the new law, the preliminary determination of less than fair value sales must come within 140 or 190 days of the initiation of an investigation, depending on a case's complexity. This compares with 180 or 270 days under previous law. In exceptional circumstances, the preliminary determination now may be announced within 90 days. 9

In addition to these changes, the 1979 Act marks the continued ascendancy of the constructed value criterion. Previously, when price comparisons with the exporters' home market were appropriate but impossible, the authorities were permitted to use constructed value only when price comparisons with third country markets were infeasible. Under the 1979 Act, they are allowed further discretion in the use of either third country or constructed value comparisons. Al though Treasury initially was instructed to continue its use of third market comparisons wherever possible, Commerce now has the option of using constructed 
value not just when there is evidence that sales fail to cover costs "over an extended period of time and in substantial quantities," but whenever necessary to meet the shortened time limits.10 Even the possibility that constructed value calculations might be substituted for third market comparisons has elicitied objections from U.S. importers and foreign producers. 11

Once again, the modifications in the new Act provided an inducement to file antidumping petitions. In March of 1980, the U.S. Steel Corporation filed a major dumping complaint against European producers, leading to the suspension of the TPM. This and subsequent petitions eventually were withdrawn after a new set of trigger prices was adopted in October. However, this second understanding was even less durable than the first. In January 1982, the steel industry lodged a new round of 132 complaints under the provisions of both countervailing duty and antidumping statutes, marking the second suspension and apparently the demise of the TPM.

In summary, the evolution of U.S. antidumping policies can be seen as a response to economic and administrative exigencies. As markets have grown increasingly integrated, criteria and procedures for determining dumping have been modified to expedite the decision-making process. Statutory and procedural changes have led to growing dependence on the constructed value criterion for dumping. Dissatisfaction with earlier procedures has provided the impetus to reduce the discretion of administrative agencies and to place greater reliance on legalistic procedures, leaving less room for negotiated solutions and encouraging the emergence of adversarial relationships. The Trigger Price Mechanism provides a clear illustration of these phenomena.

II. The Trigger Price Mechanism

The TPM was based on the following principles: (1) Treasury was to 
calculate for each product the average cost of production in Japan, which was taken as the world's most efficient producer. (2) Customs was to collect and analyze data on production costs and prices in major steel-exporting countries and to monitor imports by means of a Special Invoice for steel products, alerting Treasury of substantial or repeated shipments below trigger prices. (3) In such instances, Treasury was to initiate an antidumping investigation without waiting to receive a complaint. (4) While officially the TPM did not prevent domestic producers from exercising their rights under U.S. trade law, in fact the TPN was based on an understanding that existing dumping complaints would be dropped and no major new ones would be initiated. (5) Equally, the TPM did not prevent foreign producers from exercising their rights under U.S. antidumping statutes. Preclearance (assurance that exports under trigger price levels would not lead to the initiation of antidumping procedures) would be granted if they demonstrated that prices were not below fair value. (6) If sales at less than fair value were found and injury was established, countervaling duties were imposed on all shipments of the product by the offending producer. The level of the duty was determined by the difference between either foreign market price or constructed value and U.S. market price; that is, without reference to trigger prices.

The trigger price for each product was made up of three components: a "base price" for each product category, "extras," and transport charges. The base price reflected estimates of average cost of production in Japan. Treasury, and later Commerce, based their average cost estimates on confidential data supplied by MITI. To base prices, "extras" were added to account for additional costs associated with specifications for width, thickness, chemistry or surface preparation which differed from the base product. To these figures were 
added transport costs, including charges for Japanese inland freight, loading, ocean freight, insurance and wharfage. These charges differed for East Coast, Gulf Coast, Pacific Coast and Great Lakes shipments. Importer's sales commissions were excluded, since trigger prices were based on cost to importers, assuming that transactions were at arm's-length. If the importer was related to the exporter of the steelmill product and the transfer price did not reflect an arm's-length transaction, then the first sales price by the importer to an unrelated U.S. buyer was compared with the trigger price.

Trigger prices were calculated in dollars per metric ton (2,205 1bs) or net ton $(2,000$ Ibs), with quarterly adjustments for changes in estimated production costs, transport charges and yen-dollar exchange rates. To provide the authorities with some discretion in light of the extent of exchange rate fluctuations, a five per cent "flexibility band" was introduced to permit trigger prices to fluctuate around landed cost estimates. With the reinstatement of the TPM in 1980, the preclearance procedure and the exchange rate conversion factor were altered, and an "antisurge" provision was added, setting quantitative rules for a special review of imports in periods when steel imports were increasing and domestic capacity utilization was low.12

\section{A Calculating Trigger Prices}

Calculating Japanese production costs is a difficult task. (A representative estimate is shown in Table 1.) We focus on four problematic aspects of the cost calculation: estimating normal capacity utilization rates, adding an allowance for profits, estimating yield ratios, and converting costs in yen into trigger prices in dollars.

Estimates of normal capacity utilization rates mattered for calculating Japanese costs because the fixed cost component of total costs was divided by 
Table 1

Estimated Japanese Cost of Production (1981IV, \$/metric ton finished product)

Basic raw materials

166.60

Other raw materials

86.90

Labor

106.62

Other expenses

26.01

Depreciation

35.86

Interest

28.67

Profit

30.57

Scrap-yield credit

Source: Department of Commerce, International Trade Administration. 
normal capacity utilization rather than current capacity utilization in constructing fixed costs per ton of production. For the second and third quarters of 1978, cost estimates were based on an 85 per cent capacity utilization rate, the average for Japanese facilities over the previous 20 years. In 1978IV, Treasury switched to the average operating rate over the previous five years. Given Japan's relatively low capacity utilization rates in the mid-1970s, this change raised trigger prices by approximately $\$ 18$ per net ton. 13 This effect became even more significant as the high capacity utilization years 1973-74 left the five-year reference period. Capacity utilization assumptions significantly affected estimated Japanese costs because not only 90 per cent of depreciation and 75 per cent of interest expenses but 50 per cent of labor costs and other expenses were included in fixed costs.

In accordance with U.S. trade law, under the TPM an allowance for normal profits was added to Japanese costs in the amount of eight per cent of raw material costs, labor costs and other expenses. Like fixed costs, this allowance was divided by normal capacity utilization rather than actual capacity utilization in calculating profits per ton of production. Compared to the constructed value provision of U.S. antidumping law, there was little tendency for the profit margin to rise as the level of activity declined. However, this provision still prevented foreign firms from emulating their domestic competitors by reducing their markups and accepting lower profit margins in periods of stagnant demand.

The production cost data submitted by MITI was based on an 86.5 per cent yield ratio (tons of finished steel per ton of crude steel). U.S. producers, whose older facilities generated lower yields, claimed that some of the products that were regarded as finished by the Japanese were scrap by U.S. 
standards. Consequently, the 86.5 per cent yield was lowered to 80 per cent. Only from 1978IV, after a mission by the Steel Task Force to Japan, was the extent of Japanese superiority in steel processing and finishing recognized and incorporated into higher yield ratios of 82.7 per cent and into higher yield credits, together reducing estimated Japanese costs by as much as $\$ 15$ per net ton.14

While trigger prices were expressed in dollars, production costs, with exception of most raw materials, were denominated in yen. Since exchange rates were considerably more variable than production costs, initially yen were converted to dollars using a 60-day average exchange rate for the period prior to announcement of the current quarter's trigger prices. After reinstatement, this 60-day average was replaced by a 36-month moving average "to minimize the impact of exchange rate fluctuations on TPM levels."15 This change in the exchange rates used to convert yen to dollars significantly affected trigger price levels. 16

Table 2 illustrates the extent to which exchange rate conversion factors affected estimated Japanese production costs. For example, had Japanese production costs been based on current exchange rates, the average base price would have fallen from $\$ 395$ in $1978 I V$ to $\$ 356$ in $1979 I V$ instead of rising by $\$ 16$ over the period. Had a 36 -month average been used in this period, it is likely that the TPM would have been stillborn, because the first base price would have been $\$ 293$ instead of $\$ 328$, a difference of 11 per cent.

In the first year of the TPM, the base price rose 18 per cent, not withstanding a 2.8 per cent downward adjustment under flexibility band provisions. This rise was almost exclusively attributable to appreciation of the yen. It is not surprising that a one-year review of the TPM by the Steel 


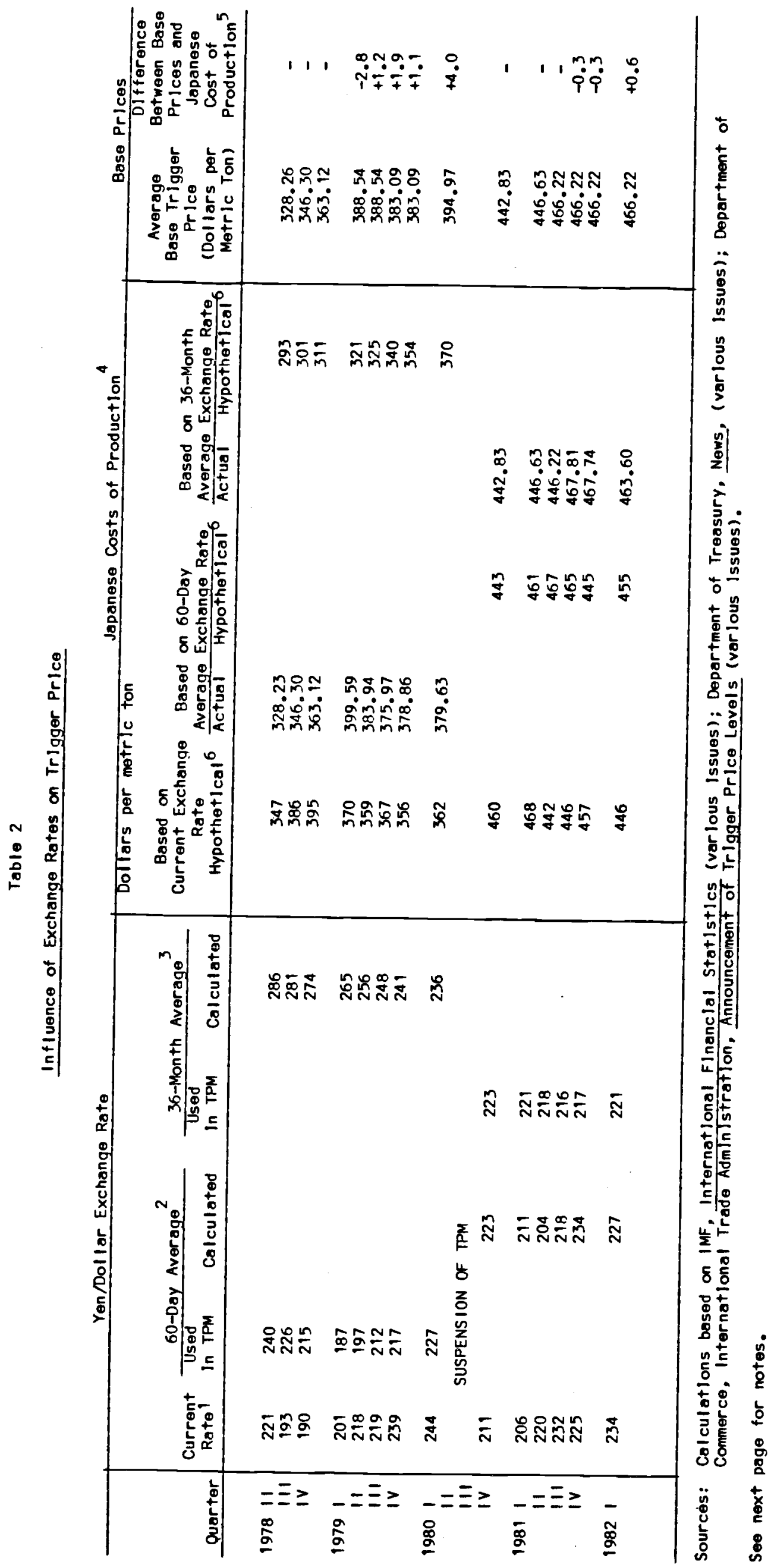




\section{Notes to Table 2}

1. Average exchange rate for the quarter.

2. The 60-day average was based on a period which terminated between one and two months before the quarter's start. In calculating the 60-day average exchange rate applied to a quarter, we average the exchange rate for the first two months of the previous quarter.

3. Average of 36 months terminating two months before the quarter's start.

4. Base prices, which are for illustrative purposes only, do not include "extras," transport costs and importation charges.

5. Japanese production cost estimates may differ from base trigger prices due to use of the flexibility band. A "plus" indicates an upward adjustment due to the flexibility band.

6. For purposes of these calculations, base prices are corrected for flexibility band effects. One-third of Japanese costs are assumed to be expressed in dollars to allow for dollar-denominated raw material imports. 
Tripartite Committee regarded it a highly successful mechanism.17 In 19791 the yen began its steep decline which was reflected in trigger prices beginning with 1979II. Rising Japanese production costs were almost entirely offset by the higher yen/dollar exchange rate: the $1980 \mathrm{I}$ base price was less than two per cent above its 1979 I level. Again, it is not surprising that the U.S. industry grew increasingly dissatisfied with the TPM's operation. The U.S. Steel Co. filed its March 1980 antidumping suits in reaction to these developments more than anything else.18 Thus, exchange rate fluctuations play a major role in explaining the suspension of the TPM.

Following reinstatement, the 36 -month average was substituted for the 60-day average. This reduced the risk that further depreciation of the yen would reduce base prices in the immediate future. The choice of exchange rate conversion factor had major implications. The most extreme instance was in 1979I, when the difference under the two exchange rate conversion factors was 20 per cent. If, in the first two years of the TPM, a 36-month average had been used, Japanese production costs in dollars would have been 12 per cent lower on average. In contrast, following the reinstatement of the TPM, the difference under the two methods was comparatively small.

The TPM's first suspension was partly the result of the depreciation of the yen and the strength of the dollar; its second suspension and demise were partly a consequence of inflation in the U.S. combined with stable Japanese production costs, in yen, and a virtually constant 36-month average exchange rate. At the same time, fluctuations of the European currencies against the dollar and the yen contributed to disintegration of the second stage of the TPM. Appreciation of the yen against most European currencies increased European producers' ability to export below trigger prices (see Table 3). Although the 




Against Yen* Agrinst "TPM-Yen"** Agginst \$*

Belgian Franc German Mark French Franc Italian Lira British Pound
$-18 \%$

$-10 \%$

$-18 \%$

$-20 \%$

$-14 \%$
$-27 \%$

$-19 \%$

$-27 \%$

$-29 \%$

$-23 \%$
$-35 \%$

$-23 \%$

$-36 \%$

$-39 \%$

$-29 \%$

* Quarter averages.

* 36-month average used in calculating Japanese production costs in dollars. ** A minus indicates an appreciation of the yen.

Source: Department of Commerce, International Trade Administration, Commerce News (various issues); International Monetary Fund, International Financial Statistics (various issues). 
impact of these exchange rate changes was mitigated to some extent by raw material prices quoted in dollars, it resulted in a proliferation of preclearance requests by European producers; for example, preclearance procedures on behalf of Hoogovens of the Netherlands indicated that they were in fact capable of exporting under trigger prices without exporting below fair value. With the realization that prospects for extensive antidumping actions were dim, the U.S. industry's focus shifted increasingly to the issue of foreign governmental subsidization, and the TPM's days were numbered.

\section{B. Economic Implications of the TPM}

The shipping cost of Japanese exports to the U.S. differs substantially by region (see Table 4). Since different trigger prices were calculated by region, owing to differences in Japanese transport costs and related factors, the system significantly distorted established trade and production patterns. The use of Japanese transport costs in the calculation of trigger prices reversed the traditional geographic relationship of relatively low Great Lakes prices to relatively high West Coast prices.19 The implications for foreign producers, other than the Japanese, depended on whether their major export market was the East Coast and Great Lakes or the Gulf Coast and the West. Regional differences in trigger prices penalized European producers whose markets were in the East relative to those whose markets were in the West. The effects were analogous for domestic firms: West Coast producers were penalized relative to East Coast and Great Lakes producers, since they faced lower priced import competition. Both the 30 per cent rise in imports on the Pacific Coast between 1977 and 1978, in a period when imports into the Great Lakes region were declining by 15 per cent, and the losses experienced by Kaiser Steel, a leading West Coast producer, in an otherwise profitable year may have reflected these 
Table 4

$\frac{\text { Importation Charges on Japanese Steel Products, 1978-II }}{\text { ( } \$ \text { per metric ton })}$

Product

Hot Rolled Carbon

Bars to:

Lakes

East

Gulf

Pacific

Cold Rolled Sheet to:

Lakes

East

Gulf

Pacific
Freight Insurance Interest Handling Total

40.83

28.13

23.59

22.69

3.49

3.36

3.32

3.31

11.18

8.77

8.66

6.68

3.63

3.63

4.54

2.72

2.42

2.34

2.31

2.31

31.76

24.50

20.87

20.87
7.77

6.14

6.05

4.68
3.63

3.63

4.54

2.72
59.13

43.89

40.11

35.40

45.58

36.61

33.77

30.58

Source: Treasury News, January 3, 1978. 
phenomena.20 Similarly, domestic steel-using industries in Ohio were put at a disadvantage relative to their competitors in California and the Southwest. European opposition to generous trigger prices in their major regional markets led Treasury to adjust downward the freight allowance to the Great Lakes, but distortions of established trade patterns remained.

In addition to regional price differentials, the product mix of imports was altered by the TPM. For some products, differences between trigger prices and U.S. mill list prices were substantial, while for others they were minor. Compare the margins (which disregard American discounting) reported in Table 5. A comparison of trigger prices and American list prices suggests that the trigger price-list price differential varied substantially. Foreign producers specializing in relatively sophisticated, expensive products objected most strenuously to large positive differentials.

Another effect was a shift by foreign producers to the sale of fabricated steel products which were exempt initially from the TPM. Imports of fabricated standard shapes were 71 per cent higher in December 1978 than in the previous year. In contrast to large increases in the price of basic steel products, the prices of TPM-exempt fabricated standard shapes increased on average by only 3.5 per cent from the previous year. 21 The wire and wire rod segment of the market provided a graphic example of incomplete coverage: the fact that initially the TPM covered wire processors' inputs but not their outputs led them to complain of negative effective rates of protection. Subsequent extensions of the TPM's coverage from 65 per cent of imports initially to 85 per cent in 19791 I reflected the Administration's recognition of this problem.

The establishment of a single reference price for a particular steel product, independent of origin, affects all foreign suppliers similarly only if 
Table 5

Trigger Price - U.S. List Price Differentials, 1978

Trigger Price

1978II, Plus

Estimated

Duties

U.S. Steel Co List Price

East Coast January 1978

Hot-Rolled Sheet

Plate

Cold-Rolled Sheet

(1)

$\$ 262$

301

Hot-Rolled Bar

Tin Plate

329

373

500

(2)
(1) $-(2)$ in $\%$ of (1) (3)

$-9$

$-7$

$-1$

$+4$

$+4$
U.S. Steel Co. (1)-(4) List Price

February 1978

$\$ 300$

323

358

345

na in $\%$
359

481

na: not available

Source: Iron Age, January 16, 1978, p. 29. 
products are homogeneous. In fact, there are significant quality differences in products which appear superficially to be homogeneous.22 Prior to the TPM, foreign suppliers of low quality steel could use low prices to compete with suppliers of higher quality products. This was more difficult under the TPM, which tended, other things equal, to divert trade from suppliers of low-quality steel to suppliers of high-quality products.

In theory, the TPM was based on prices charged by exporters to unrelated U.S. customers, or by related importers to subsequent unrelated customers. However, when the exporting and importing companies were related, the proper measure of compliance often was difficult to observe. Domestic customers could delegate steel purchases to a foreign branch or open an offshore trading firm to buy foreign steel below trigger prices and export it to the U.S. above trigger prices. Similarly, foreign producers with downstream investments in steel processing in the U.S. could respect trigger prices in sales to U.S. subsidiaries, merely transfering profits from the U.S. subsidiary to the foreign base without affecting any physical transactions. The rise of related party transactions from 40 to 60 per cent of total imports in the first year of the TPM is suggestive of the extent of these practices.23 In response, Commerce changed its related party monitoring procedures to include an ex mill price monitoring policy and new rules to evaluate unrelated resale prices.

Economic considerations provided importers and exporters with obvious incentives to circumvent the Customs Bureau's policing mechanism. The indictment of the Japanese trading company, Mitsui, for defrauding the United States provides an indication of the techniques available to an importer.24 To circumvent the TPM and the Antidunping Act, Mitsui admitted to having reported falsely inflated invoice prices and to having reduced actual payments by customers by 
arranging false contract cancellation confirmations, which entitled the customer to cancellation penalties; by providing refunds for false damage claims, misproductions or other debit memoranda; by paying commissions to a foreign parent company of an American customer; and by making "currency adjustment" payments based on a secret "yen/dollar exchange rate agreement." It also admitted to predating contracts to shift the apparent sales date into the period when the TPM was suspended.

We have no way of estimating the prevalence of such practices, but it is clear that insuring compliance is one of the major problems confronting architects of schemes for administered protection such as the TPM. To understand these problems better, it may help to look more closely at the motivation for dumping itself.

\section{Models of Dumping}

Although a number of explanations for dumping, defined either as price discrimination in international trade or as sales below costs of production, are current in policy circles, few of these arguments have been subjected to formal analysis. In this section, we first review the popular explanations, starting with the "modern" definition of dumping as sales below costs of production, before proceeding to the alternative definition of the practice as international price discrimination. Finally, we present a theoretical model of what seems to us a particularly important explanation for dumping in the international steel trade: international differences in industry structure and conduct in imperfectly competitive, segmented markets.

Until recently, there have been few formal models of reasons why firms may persist in exporting at prices below production costs. It is well known, of course, that in perfectly competitive markets where firms equate price with 
marginal cost, it may be optimal to continue operating at a loss during periods of depressed demand so long as revenues cover variable costs. However, this does not seem to be quite what those who criticize sales below costs have in mind. Rather, they seem to be objecting to practices which imply that firms have departed from their cost curves and are engaged in questionable practices, possibly predatory in nature. Ethier (1982) has presented a model in which competitive firms not only export at prices below costs but appear to depart from their supply curves when demand is unusually depressed. He assumes that firms are constrained to negotiate wage contracts before the state of demand is known, and that they are incapable of responding to a demand shortfall by renegotiating wages. Their only option is to lay off laborers whose contracts can be terminated. Since they are not permitted to accumulate inventories, firms may have no choice but to sell output at prices below average cost when demand is unfavorable. The unique feature of the model is that there are circumstances in which it is optimal for firms to practice restraint in laying off workers even when labor's wage exceeds its marginal product. Ethier assumes that employers and employees share knowledge of the shape of the wage-employment tradeoff. Firms which retain some workers when demand is depressed despite the fact that labor's wage exceeds its marginal product are able to pay lower wages, other things being equal, when demand is buoyant. Thus, firms engage in practices that bear little resemblance to a strategy of minimizing losses in the face of fixed costs and that can be construed as predatory dumping. In fact, they are merely acting in their preceived long-run interest, given conditions in factor and product markets.

Other explanations for the persistence of pricing below apparent variable costs are based upon dynamic considerations. In Eichengreen (1982) we 
analyze several dynamic models. We formalize the claim that firms dump intermittently to attract other firm's loyal customers, referred to by Stegemann (1980) as the "short-sighted buyer" argument. The firm's problem is formulated in standard dynamic optimization terms, where the number of customers to whom it can sell is a slowly adjusting variable which depends on the firm's past pricing policy. In response to disturbances, the firm may find it optimal to reduce price below variable cost in order to augment its stock of customers. At each point in time, the firm equates current marginal cost with marginal revenue from current sales plus the present value of future sales to customers acquired as a result of current pricing policy. This practice, which in fact equates marginal cost with shadow marginal revenue, resembles dumping nonetheless.

We also formalize the argument that firms may price below the standard markup and perhaps below current variable cost in periods of depressed demand due to additional costs of adjusting the level of production. Again, the dynamic optimization problem is standard, except that we include an adjustment cost term, specified as an increasing function of the percentage change in output. The optimal response to a permanent decliñe in demand is fairiy intuitive. As the unanticipated demand shortfall occurs, the firm must sharply reduce its price, since it is costly to cut production in response to the exogenous decline in demand. Over time, the firm reduces production at the optimal rate, given adjustment costs, permitting it to increase the price charged for its output. Al though the firm is simply equating marginal revenue with shadow marginal cost, the initial price cut again resembles dumping.

Another popular dynamic argument is that dumping results from firms' concern with the economics of learning-by-doing. If firms wish to move down their learning curves, they may sell output at prices where current marginal 
costs are less than current marginal revenues. If higher output now reduces costs of production later, then the solution to a firm's dynamic optimization problem is to set current marginal cost equal to the sum of current marginal revenue plus the present value of the indirect saving on future production costs. Spence (1981) has analyzed this problem for the closed economy, and Krugman (1982) has extended the analysis to the case of international competition.

The other explanations for dumping we have labelled the "traditional" view. In textbooks, dumping is explained as price discrimination between national markets by foreign producers facing a price elasticity of demand in the export market that exceeds the price elasticity of demand in their own market.25 Permitting foreign suppliers to discriminate in favor of domestic consumers reduces the surplus captured by domestic rivals but by less than the increase in the surplus captured by domestic consumers. Domestic competitors have an incentive to lobby for restrictions on price discrimination by foreign suppliers, while policymakers seeking to maximize national welfare have an incentive to resist. 26

A limitation of the textbook explanation of dumping as monopolistic price discrimination is that different price elasticities of demand are assumed to arise arbitrarily from taste differences among residents of home and foreign countries. As Brander and Krugman (1981) note, this explanation provides little guidance as to instances when we should expect to observe dumping rather than reverse dumping or no price discrimination at all.

We proceed by analyzing the textbook explanation for dumping as price discrimination in international trade. However, instead of assuming arbitrary differences in demand, we emphasize systematic differences in supply. 
Specifically, we focus on aspects of market structure and conduct which can lead to price discrimination in favor of overseas customers. To highlight these factors, we assume, until explicitly stated to the contrary, that commodity demands in the home and foreign countries are identical. Thus, dumping cannot arise from arbitrary differences in tastes. To further simplify the exposition, we assume throughout the theoretical analysis that the common price elasticity of demand $\varepsilon$ is constant and exceeds one in absolute value.

We analyze a model made up of two regions (or "countries"): the importing and exporting, or domestic and foreign, countries. As the nonenclature suggests, the model does not admit of trade-pattern reversals or two-way trade in identical products. It is necessary to rule out re-exports by assumption, for in their presence price discrimination (net of transport costs) is impossible. Any one of several restrictions is sufficient to preclude this possibility; for simplicity we assume that the exporting country's market is protected by prohibitive trade restrictions. We consider a number of specific market structures under which dumping may occur. Market structure is taken as parametric in that entry and exit are not permitted. Models of dumping as entry deterrence are considered in Eichengreen (1982), but such considerations are omitted here as not being essential to a relatively short run analysis of the steel industry.

The implication of the analysis is the same in each case: dumping will occur when firms producing for sale to customers in the importing country find it relatively difficult to restrict output to the joint-profit-maximizing level. The incidence of dumping will depend on the number of firms producing for each national market, their costs, their market shares, and the degree to which they recognize and exploit their mutual dependence. 
Assume initially that a homogeneous commodity $Z$ is produced at home and abroad by identical single-product firms, subject to a fixed cost $F$ and a constant variable cost c.

$$
\begin{aligned}
& C_{\ell}=F+c\left(y_{\ell}\right) \\
& C_{i}^{*}=F^{*}+c^{*}\left(x_{i}+x_{i}^{*}\right)
\end{aligned}
$$

$C\left(C^{*}\right)$ is total cost of domestic (foreign) firms.27 Asterisks denote foreign values throughout. $y_{\ell}$ is domestic firm $\ell$ 's production for the domestic market, and $x_{i}$ and $x_{i}^{*}$ are foreign firm $i$ 's production for the domestic and foreign markets, respectively. The constant variable cost assumption is dispensible, but it makes for expository simplicity. Its realism is addressed below.

The industry in each country is comprised of a small number of oligopolistic rivals. Initially, we assume that all such firms abide by the cournot rule, setting quantities under the assumption that rivals' supplies to each market are fixed. There are a variety of richer strategies available to the firm, but this assumption provides a reasonable starting point. Here and below, we consistently assume that second order and stability conditions are satisfied. Each firm maximizes profits $\left.\pi^{*}\right)$ subject to its rivals' behavior. It is possible that firms owned or operated by government agencies pursue other objectives, but we restrict our attention here to the implications of profit maximization. For a representative foreign firm:

$$
\pi_{i}^{*}=p(z) x_{i}+p^{*}\left(z^{*}\right) x_{i}^{*}-c_{i}^{*}\left(x_{i}+x_{i}^{*}\right)-F_{i}^{*}
$$

where $z$ is total supply to the domestic market $\left(z=\sum_{i=1}^{k} x_{i}+\sum_{\ell=k+1}^{m} y_{\ell}\right)$ and 
$z^{*}$ is total supply to the foreign market $\left(z^{*}=\sum_{i=1}^{k} x_{i}^{*}\right)$. There are $k$ foreign firms and $m-k$ domestic firms. $p$ and $p^{*}$ are the domestic and foreign prices of Z. $\partial \pi_{i}^{*} / \partial x_{i}^{*}$ implies that:

$$
p^{*}-\left(p^{*} / \varepsilon\right)\left(x_{i}^{*} / z^{*}\right)=c_{i}^{*}
$$

where $\varepsilon=\frac{-d z}{d p} \frac{p}{z}$ is the price elasticity of market demand. Multiplying by $\mathbf{r}_{i}^{*} / \mathbf{z}^{*}$ and suming over the $k$ firms which produce for sale to foreign customers yields:

$$
\mathrm{p}^{*}-\left(\mathrm{p}^{*} / \varepsilon\right) \mathrm{H}^{*}=\hat{c}^{*}
$$

where $\hat{c}^{*}=\sum_{i=1}^{k} \frac{x_{i}^{*}}{z^{*}} c_{i}^{*}$ is the share-weighted average of the variable costs of foreign firms, and $H^{*}=\sum_{i=1}^{k}\left(\frac{x_{i}^{*}}{z^{*}}\right)^{2}$ is the Herfindahl Index of foreign sales concentration. 28 Since the markup over marginal cost is an increasing function of $\mathrm{H}^{*}:$

$$
\frac{p^{*}}{\hat{c}^{*}}=\frac{\varepsilon}{\varepsilon-H^{*}}
$$

the ratio of foreign to domestic prices (the "dumping ratio") is: 


$$
\frac{p^{*}}{p}=\frac{\hat{c^{*}}}{\hat{c}} \cdot \frac{E-H}{E-H^{*}}
$$

Here $\hat{c}$ is a share-weighted average of variable costs for firms selling to the domestic market, and $H$ is the Herfindahl Index of domestic sales concentration, defined over both domestic and foreign firms. Note that the Herfindahl Index measures the extent to which sales to customers in a given country (as distinct from production by firms located in that country) are concentrated among a small number of rivals. The first term in (6) indicates that price will be lower in the market where on average suppliers produce subject to lower variable costs. The second term in (6) indicates that the domestic price/cost ratio will be lower than the foreign one when the domestic market is less concentrated than the foreign market as measured by the Herfindahl Index. The greater the degree of concentration in sales, the closer the oligopolists are able to approach the joint-profit-maximizing solution.

The intuition for this result is apparent. Equation (3), from which the dumping ratio is derived, indicates that the firm sets perceived marginal revenue equal to marginal cost. Perceived marginal revenue depends not only on market price and market elasticity of demand but in addition on the individual firm's market share. A smaller market share increases the elasticity of the firm's perceived marginal revenue function by reducing its loss of revenue on inframarginal sales.

A special case is where all firms produce subject to identical costs. In this case, all firms selling in a particular market have identical market shares, and the Herfindahl Index is simply that number of firms raised to the second power. Dumping occurs when more firms produce for sale to the domestic 
market than to the foreign one, which is necessarily the case in this instance given our other assumptions. The sales of each domestic firm are $z / m$, so profits of each firm are $[p(z)-c] z / m-F$. Thus, while our model focuses on the price discrimination definition of dumping, it is compatable with the sales below cost criterion analyzed by Ethier (1982) and others, for it is entirely possible in our model for profits to be negative during periods of depressed demand.

It is straightforward to generalize the dumping ratio to allow firms to anticipate the reactions of rivals and to introduce a competitive fringe in each market. To introduce the fringe firms, define:

$$
\begin{aligned}
& x^{*}=\sum_{i=1}^{k} x_{i}^{*}+\sum_{\ell=k+1}^{n} x_{\ell}^{*} \\
& x=\sum_{i=1}^{k} x_{i}+\sum_{\ell=k+1}^{n} x_{\ell} \\
& y=\sum_{q=n+1}^{s} y_{q}+\sum_{u=s+1}^{w} y_{u}
\end{aligned}
$$

where there are $n-k$ members of the foreign competitive fringe and $w-s$ members of the domestic competitive fringe. Each domestic oligopolist maximizes the expression:

$$
\pi_{q}=p(z) y_{q}-c_{q}\left(y_{q}\right)-F_{q}
$$

The first order condition is:

$$
p+y_{q} \frac{\partial p}{\partial z}\left(\frac{\partial z}{\partial y_{q}}+\sum_{i=1}^{n} \frac{\partial x_{i}}{\partial y_{q}}+\underset{q \neq r}{w} \frac{\partial y_{r}}{\partial y_{q}}\right)=c_{q}
$$


We assume that oligolopolists neglect the reaction of fringe firms $\left(\sum_{u=s+1}^{w} \frac{\partial y_{u}}{\partial y_{q}}=\sum_{\ell=k+1}^{n} \frac{\partial x_{\ell}}{\partial y_{q}}=0\right)$ and that members of the fringe act as price takers, setting price equal to marginal cost. For algebraic simplicity, we assume that each firm's conjecture about the reaction of each rival is identical. 29

Multiplying by $y_{q} / z$ (or by $x_{i} / z$ ) and summing over firms producing for the domestic market yields an expression that can be rearranged to yield:

$$
\hat{p}=\frac{\varepsilon}{\varepsilon-\tilde{H}(1+\delta)}
$$

where $\tilde{H}$ is the truncated Herfindahl Index for the $k+s-n$ largest firms selling to the domestic market, and $\delta$ is the conjectural variation on rival s' domestic sales.30 The dumping ratio is:

$$
\frac{p^{*}}{p}=\frac{\hat{c^{*}}}{\hat{c}} \cdot \frac{\varepsilon-\tilde{H}(1+\delta)}{\varepsilon-\tilde{H}^{*}\left(1+\delta^{*}\right)}
$$

where $\tilde{H}^{*}$ is the truncated Herfindahl Index for foreign firms, defined over shares of foreign sales, and $\delta^{*}$ is the conjectural variation on foreign rivals foreign sales. Thus, the dumping ratio depends on costs, on market demand elasticities, and on (truncated) Herfindahl Indices, now adjusted for conjectural variations. The dumping ratio is a decreasing function of the conjectural variation in the domestic market, since the larger the conjectural variation, the greater the perceived threat of retaliation by rivals to an individual firm's price reduction.

It is a small step to derive the analogous expression when domestic and 
foreign outputs are imperfect substitutes. Let $p^{\prime}=p^{\prime}(y, p)$, where $p^{\prime}$ is the price of home output in the domestic market, and $p$ is the price of foreign output in the domestic market. For simplicity of exposition, we retain the assumption that the foreign market is closed to imports; thus $p^{*}=p^{*}\left(x^{*}\right)$. It will be necessary to consider two price ratios. Denote the market share of the domestic fringe $\theta$. Each domestic oligopolist maximizes the expression:

$$
\pi_{q}=p^{\prime}(y, p) y_{q}-c_{q}\left(y_{q}\right)-F_{q}
$$

The first order condition is:

$$
p^{\prime}+y_{q} \frac{\partial p^{\prime}}{\partial y}\left(\frac{\partial y}{\partial y_{q}}+\sum_{q \neq r}^{s} \frac{\partial y_{r}}{\partial y_{q}}+\sum_{u \neq v}^{w} \frac{\partial y_{v}}{\partial y_{q}}\right)+y_{q} \frac{\partial p^{\prime}}{\partial p} \frac{\partial p}{\partial y_{q}}=c_{q}
$$

For algebraic simplicity, we again assume that each domestic oligopolist's conjecture about the reaction of each domestic rival is identical. It is convenient to impose two further assumptions: that each domestic oligopolist makes the same conjecture about the response of foreign suppliers to a percentage change in its output ( $\Psi=\frac{\partial p}{\partial y_{q}} \frac{y_{q}}{p}$ is the same for all q), and that each domestic oligopolist forms the same estimate of the ratio of cross- to own-price elasticities in the demand for its output (that is, each makes the same estimate of $\left.\alpha=\frac{\partial p^{\prime}}{\partial p} \frac{p}{p^{\prime}}\right)$. Recalling that oligopolists neglect the fringe' reaction $\left(\sum_{u=s+1}^{w} \frac{\partial y_{u}}{\partial y_{q}}=0\right)$ and that members of the fringe act as price takers, multiplying by $\frac{y_{q}}{z}$ and summing over domestic firms yields.: 


$$
\frac{\underline{p}^{\prime}}{\hat{c}^{\prime}}=\frac{\varepsilon^{\prime}}{\varepsilon^{\prime}(1+\sigma)-\tilde{H}_{y}(1+\delta)}
$$

where $\sigma=(1-\theta) \alpha \Psi, \hat{c}^{\prime}$ is the share-weighted average of variable costs for domestic firms, and $\varepsilon^{\prime}$ is the elasticity of demand for the domestic good, as distinct from the elasticity of demand for the foreign good (still denoted $\varepsilon$ ). $\tilde{\mathrm{H}}_{\mathrm{y}}$ is the truncated Herfindahl Index for the $s-n$ largest domestic firms, and $\delta$ is now the conjectural variation on domestic rivals' behavior. Making the same assumptions about foreign firms, the dumping ratio is:

$$
\frac{p^{*}}{p}=\frac{\hat{c}^{*}}{\hat{c}} \cdot \frac{\varepsilon\left(1+\sigma^{*}\right)-\tilde{H}_{X}^{*}\left(1+\delta^{*}\right)}{\varepsilon-\tilde{H}_{\mathbf{X}^{*}}^{*}\left(1+\delta^{*}\right)}
$$

and the ratio of imported to domestic steel prices is:

$$
\frac{p}{p^{\prime}}=\frac{\hat{c}}{\hat{c}^{\prime}} \cdot \frac{\varepsilon}{\varepsilon^{\prime}} \cdot \frac{\varepsilon^{\prime}(1+\sigma)-\tilde{H}_{y}(1+\delta)}{\varepsilon\left(1+\sigma_{x}^{*}\right)-H^{*}\left(1+\delta^{*}\right)}
$$

where $\tilde{\mathrm{H}}_{\mathbf{x}}^{*}\left(\tilde{\mathrm{H}}_{\mathbf{x}^{*}}^{*}\right)$ is the truncated Herfindahl Index defined over shares of sales of the $k$ largest foreign firms in the domestic (foreign) market. Again, the dumping ratio depends on (truncated) Herfindahl Indices adjusted for conjectural variations. The ratio $p / p^{\prime}$ is a decreasing function of the conjectural variation in the domestic market, since the larger the conjectural variation, the greater the extent of retaliation anticipated by firms contemplating a price reduction. Now however, the dumping ratio also depends on market demand elasticities adjusted for the effects of $\sigma^{*}$. $\sigma^{*}$ reflects foreign firms estimates of the substitutability of national outputs $\alpha$ and foreign firms' conjectures 
on their domestic rivals reactions to import price cuts $\Psi$. The larger foreign firms' conjectures on the reaction of domestic firms to an import price reduction, the less the temptation to cut prices.

The welfare effects of antidumping actions are illustrated in Figure 1, with zero subscripts denoting initial prices and quantities. We consider the case where domestic and foreign outputs are imperfect substitutes for one another and analyze the effects of an antidumping action which effectively places a floor $p_{1}$ beneath the price of imports. Income effects are neglected throughout. Before any antidumping action, there is a distortion in each market due to the presence of imperfect competition. When the price of the importable is raised from $p_{0}$ to $p_{1}$, rents accruing to foreign suppliers change by areas E-B. E-B may be positive, in part since foreign producers were incapable previously of restricting output to joint-profit-maximizing levels. Even in this case, however, foreigners may object to antidumping initiatives, since under the assumptions of the model any one foreign producer expects to increase its profits by expanding supply and driving down prices. It is possible for $E-B$ to be negative if $p_{1}-p_{0}$ is large and if the denend for imports is depressed sufficiently below the joint-profit-maximizing level.

The rise in the price of imports shifts the demand curve for domestic output to the right. However, due to our assumption of a constant demand elasticity and no change in firms' conjectures, domestic producers do not raise prices in response to the shift in domestic demand. In this model, if domestic rents are zero initially, they remain zero. In this case import restraints do not increase the profitability of domestic production, and domestic producers derive little if any benefit from the imposition of antidumping duties or similar trade restrictions. In general, the change in domestic rents equals $F+G$. 


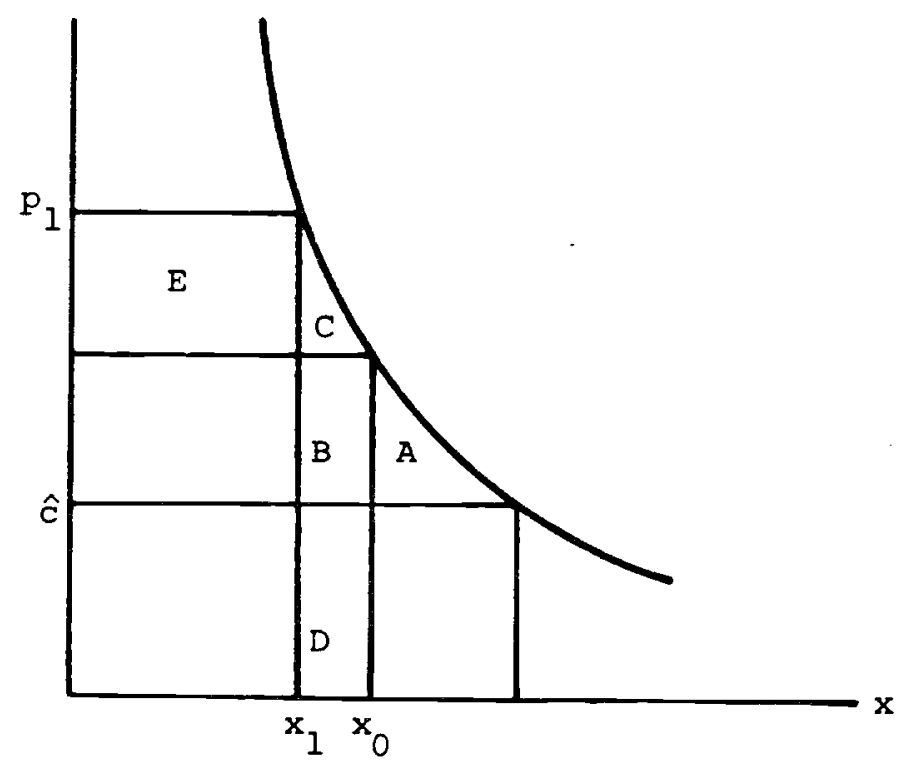

Imported steel

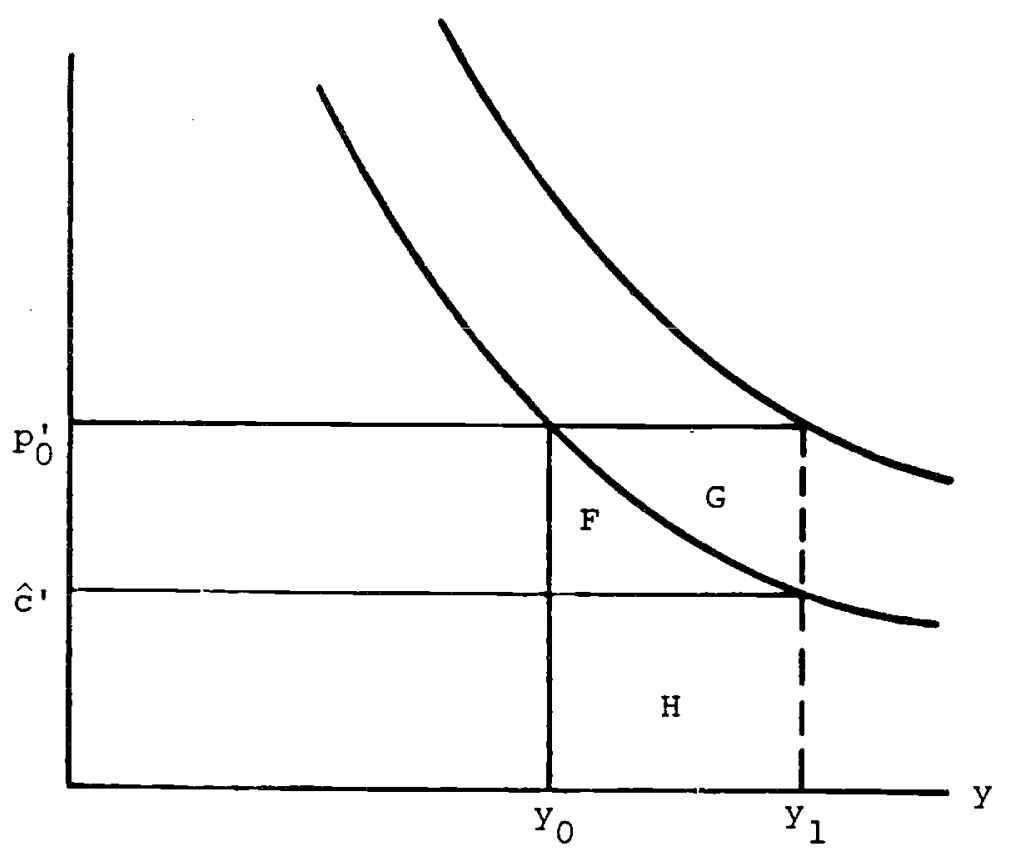

Domestic Steel 
The implications for domestic consumers are straightforward. Consumers suffer a loss of surplus in the market for $x$ amounting to areas $C+E$. Since the marginal utility of $y$ equals the price consumers pay, there is no change in consumer surplus in the market for domestic steel.

To measure the welfare loss associated with an antidumping action which raises the price of $x$ from $p_{0}$ to $p_{1}$, we employ Harberger's (1974) standard formula $-\Delta W=1 / 2 \sum_{i} \Delta T_{i} \Delta Q_{i}+\sum_{i} T_{i} \Delta Q_{i}$, where $\Delta W$ is the change in welfare, $Q_{i}$ is the quantity demanded, and $T_{i}$ is the distortion due to the divergence of price from marginal cost. The first term in this sumation approximates area $C$ in the top panel of Figure 1. $\sum_{i} T_{i} \Delta Q_{i}$ approximates areas $F+G-B$. $B$ is the extra loss in the market for $x$ due to the presence of a previous distortion also working to restrict demand. $F+G$ is the welfare gain in the market for $y$, since raising the price of imports stimulates demand for another good whose production is depressed by the presence of second distortion. Thus, for the welfare loss we have the expression $-\Delta W=(B+C)-(F+G)$.

IV. Some Numerical Estimates

In this section, we calibrate the model of Section III in order to illustrate how the extent of dumping and the TPM's effects depend on the model's parameters. We calibrate the model for 1979, the latest year for which the necessary data is available and the TPM was in effect. Readers familiar with previous efforts along these lines will note the resemblance of our approach to those of Crandall (1981) and Tarr (1982a). Our framework differs from theirs, however, in that we highlight the presence of imperfect competition.

One way to proceed is to estimate pricing equations with time series data. The results of the previous section indicate that the dumping ratio should be a function of the market demand elasticities, Herfindahl Indices, and 
conjectural variations. Using time series methods to estimate this relationship is appealing, but in this instance there are a number of impediments to implementing this approach. Consistent time series on the value and volume of precisely defined categories of European steel exports can be constructed only from 1960 or 1966. The small size of the sample is problematic when the pricing equation is nonlinear, as is the case in Section III. A further difficulty is that certain variables of interest, such as the conjectural variation, are unobservable. While the use of proxies is feasible, it is unlikely in practice to yield definitive conclusions. In preference to time series estimation, we choose to examine what data are available and to use ther as a basis for calibrating the model. The parameter values imposed are best thought of as informed guesses of the relevant magnitudes. Given that our model is highly simplified and our parameter values certainly are not above dispute, we would prefer our estimates to be viewed as numerical illustrations of how the extent of dumping and the TPM's effects depend on particular parameters.

\section{A. Data}

A number of sources provide information on the domestic and foreign prices of steel products. However, there are difficult and well-known problems in establishing a concordance between U.S. statistics and those of other nations. In this section we examine data on the price of European steel exports to the U.S. relative to the price of the same goods in Europe, since European producers were among the exporters most heavily affected by U.S. trigger prices. While official base prices for European steel products are readily available, the prevalence of discounting in the European steel market renders them a poor proxy for transactions prices. We choose instead to examine unit value figuress derived from international trade statistics. Thus, for the price of European 
steel in Europe, we use unit values of intra-E.C. trade. By implication, we neglect discounting by European producers in sales to their favored domestic customers. Unit values are themselves imperfect proxies for transactions prices; a number of authors have shown that changes in calculated unit values tend to lag behind changes in transactions prices. While this problem should be borne in mind, it is more important in other applications than when trade figures are annual totals and when one set of unit values is deflated by another.

Calculated unit values for European exports have been employed previously by Tarr (1979, 1982b) and Takacs (1982). However, their figures are not appropriate for our purposes, since they do not distinguish European exports to the U.S. from European exports bound for other destinations. Our figures for unit values of European steel exports to the U.S. and intra-E.C. steel trade, drawn from the E.C.'s Analytical Tables of Foreign Trade, are available at a low level of aggregation, permitting us to present statistics for relatively homogeneous product categories. For example, we consider only concrete reinforcing bars, eliminating other bars from that category, and remove hot rolled sheet and plate from the figures for sheet and plate less than $3 \mathrm{~mm}$. used by Tarr and Takacs. While product-mix effects may not be eliminated entirely, their influence should be minimized by our use of narrow product catagories.

Table 6 presents the ratio of domestic to export prices for four categories of European steel products: rails, wire rod, concrete reinforcing bars and cold rolled sheet. The dumping ratios exhibit a striking degree of variation. Regressing the unit value of exports destined for the U.S. on a constant term and the intra-E.C. export unit value leads in every case to rejection of the joint hypothesis of a zero constant and a slope coefficient of 
Table 6

Relative Price of European Steel Exports to U.S.

("Domestic" Unit Value Relative to Export Unit Value)

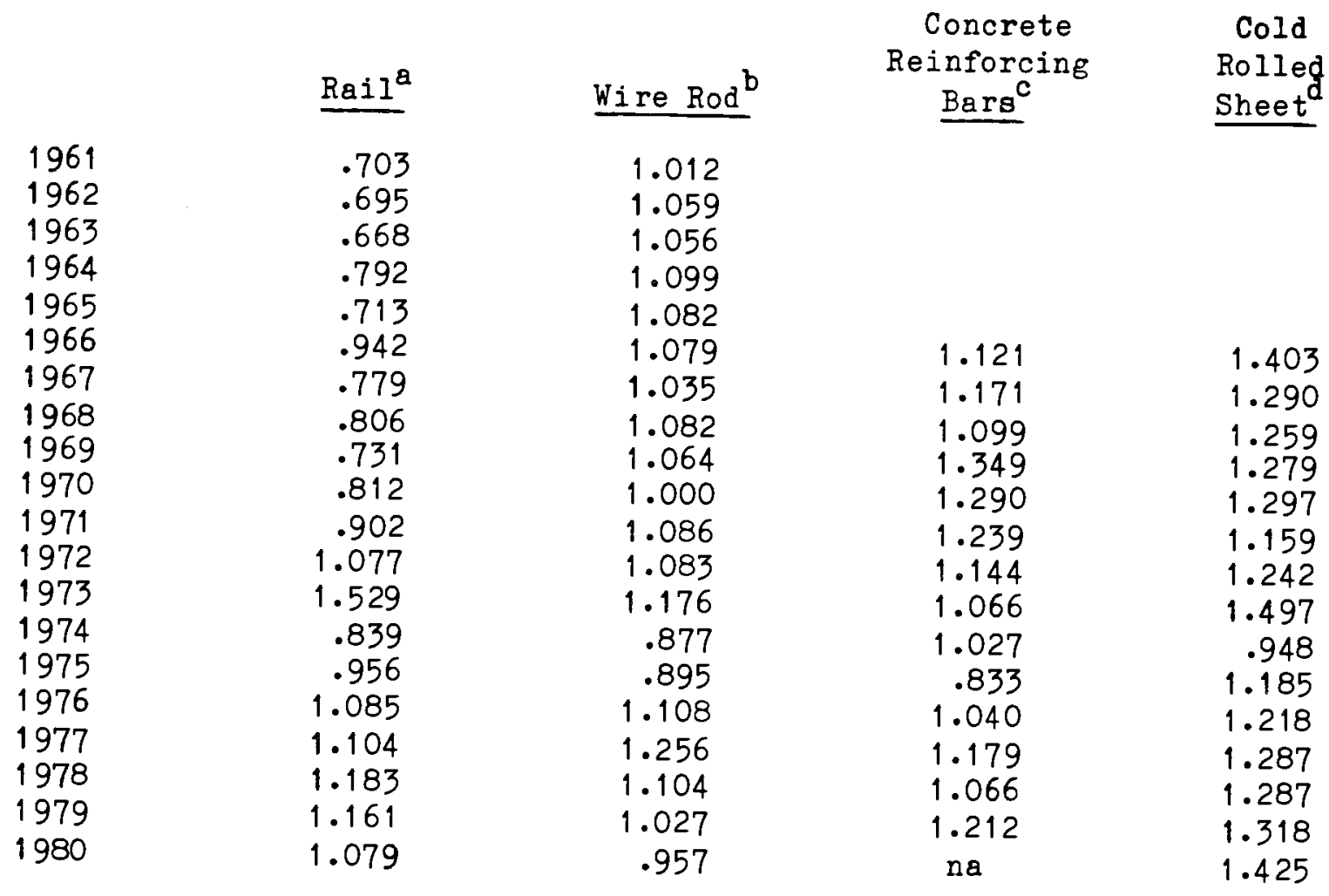

na. not available

a. NIMEXE $7316.14,7316.16$

b. NIMEXE $7310.11,7363.21,7373.23,7373.24,7373.25,7373.26,7373.29$

c. NIMEXE 7310.13

d. NIMEXE $7313.43,7313.45,7313.47,7313.49,7313.50,7313.92,7365.55$, $7365.81,7375.63,7375.64,7375.69,7375.83,7375.84,7375.89$

Note: Values greater than one indicate price discrimination in favor of the
U.S. Source: E.C., Analytical Tables of Foreign Trade (various issues). 
unity.31 Interestingly, the dumping ratios in Table 6 are similar to the price differentials of up to 40 per cent reported by Kravis and Lipsey (1977) for German-American trade in bars and in tube and pipe fittings.

\section{B. Dumping Ratios}

Our calculated dumping ratios will differ greatly depending on whether U.S. and imported steel products are treated as perfect or imperfect substitutes. Evidence on this issue is far from conclusive. Many carbon steel products appear undifferentiated - concrete reinforcing bars being perhaps the best instance in our sample. At the same time, as noted in Section II, subtle quality differences are cited frequently in studies of import penetration. The imperfect substitutes assumption is supported by all recent empirical studies, so we adopt it here.

Prices are assumed to be set in accordance with a generalized version of $\left(19^{\circ}\right)$. For European steel:

$$
\frac{p^{*}}{p}=\frac{\hat{c^{*}}}{\hat{c}} \cdot \frac{\varepsilon^{*}}{\varepsilon} \cdot \frac{\varepsilon\left(1+\sigma^{*}\right)-H^{*} x^{(1+\delta)}}{\varepsilon^{*}-H^{*} x^{*}\left(1+\delta^{*}\right)}
$$

In contrast to $\left(11^{\circ}\right)$, market demand elasticities $\varepsilon\left(\varepsilon^{*}\right)$ are allowed to differ, and we consider standard Herfindahl Indices. For price elasticities of demand, we draw on work by Stone (1979). For iron and steel semi-manufactures, stone reports import demand elasticities of 2.83 and 1.66 for the U.S. and E.C. respectively. We use 1.66 as the market demand elasticity for Europe and 2.83 as the own-price elasticity of demand in U.S. import demand functions.

In constructing Herfindahl Indices, we treat each national European industry as a joint-profit maximizer. While it is a drastic simplification, we impose this assumption in recognition of the extent of nationalization and per- 
vasive government involvement in the various national industries. Thus, the Herfindahl Indices measure the extent to which sales by European producers, either to the U.S. market or within the E.C., are concentrated nationally. For 1979 values for $H_{X^{*}}^{*}$ and $H_{x^{*}}$, calculated as in Table 6 and weighted by product shares are .335 and .215 respectively. Relaxing the assumption of joint profit maximization would tend to lower the Herfindahl indices and reduce the pricecost margins. For the conjectural variations, we consider the cournot and constant market share values of zero and unity. $\sigma^{*}$ is calibrated at 0 and -0.1. In the absence of contrary evidence, we set $\hat{c^{*}} \hat{c}$ to to unity.

The dumping ratios for 1979 generated by equation (12) are presented in Table 7. For the parameter values considered, the dumping ratio falls within the range of values appearing in Table 6 .

\section{The TPM's Effects}

For purposes of our calculations, it is necessary to consider the supply response of Japan and other exporting nations against whom the TPM was not primarily directed. If, for example, trigger prices restrict exports by the E.C. and other suppliers whose costs are high relative to those in Japan, the incipient change in U.S. import prices may elicit increased exports by suppliers whose costs are relatively low. The effects will be smaller the larger the supply response of the so-called "restrained suppliers," to use the terminology of Tarr (1982a).32 In our view, while restrained suppliers possessed considerable excess capacity both prior to and in the period of the TPM, they resisted the temptation to increase exports to the U.S. Hence, we assume no supply response by restrained suppliers to the imposition of trigger prices. In the welfare calculations that follow, we treat their supply curves as inelastic and their markets as undistorted. In this and other respects, our analysis is 
Table 7

Calculated Dumping Ratios $\left(p^{*} / p\right)$

$\delta$

\begin{tabular}{|c|c|}
\hline 0 & 1 \\
\hline 1.158 & 1.549 \\
1.063 & 1.409 \\
\hline
\end{tabular}

$$
\frac{\sigma=-0.1}{\delta^{*}}
$$

$\delta$

\begin{tabular}{l|c|c|}
0 & 0 & 1 \\
\hline 1 & 1.033 & 1.382 \\
0.937 & 1.314 \\
\hline
\end{tabular}

Source: See text. 
partial equilibrium.

In what follows, we distinguish three categories of steel: steel produced domestically, steel imported from Europe, and steel imported from other countries. Each of our denand functions has their three respective prices as arguments. As a first approximation, we treat foreign producers other than European as restrained suppliers.

We model the TPM as simply placing a floor under the price of U.S. imports at the 1979 average trigger price of $\$ 350$ per net ton. Thus, we neglect problems of non-compliance and related complications discussed in Section II. To quantify the TPM's effects, we use equations such as (12) to calculate the prices that would have obtained in the mechanism's absence. To do so, it is necessary to select specific values for $\hat{c}$ and $\hat{c}^{\prime}$. The ratio of domestic to foreign costs is a fiercely debated issue which cannot be resolved here; we set $\hat{c} \hat{c}$ ' equal to 1.2 , and for upper and lower bounds we calibrate $\hat{c}$ at $\$ 230$ and $\$ 290$ per net ton. 33 We do not distintuish U.S. exports from domestic sales. U.S. exports are small in volume and value; adding this distinction would only modify our measures in minor ways at the cost of further complexity. In the absence of precise estimates, we set the own-price elasticity of demand for domestic steel to unity and all cross-price elasticities to half the value of own-price elasticities, thereby insuring that demands are homogeneous of degree zero in prices. Given the manner in which U.S. mill list prices appear to have hovered around trigger prices, we set the price of domestic steel to $\$ 350$ per net ton.

The results of our numerical calculations are shown in Table 8 for the cases where the TPM would be binding. As indicated above, the magnitude of the effects and the sign of the net change in welfare depend largely on whether the 
Table 8

Illustrative Effects of the TPM, 1979

(in $\$$ million)

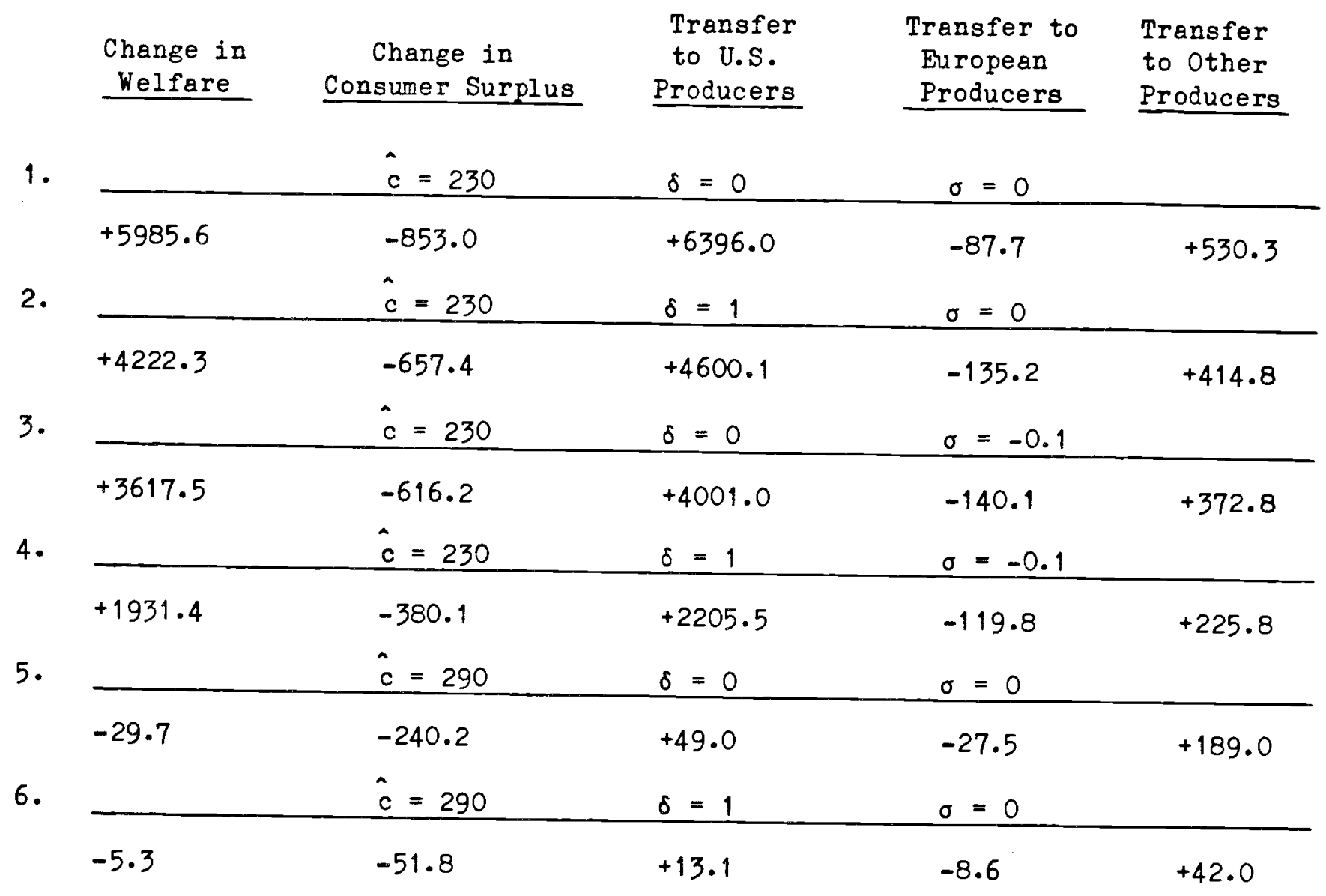

Source: See text. 
initial distortion in domestic markets is large relative to the rise in import prices caused by the TPM. In cases (1) through (4), the domestic distortion is large and the welfare effects are easily interpreted. European producers suffer a loss of surplus, while U.S. producers and foreign restrained suppliers receive aditional rents. Since the markup charged by domestic producers is relatively large, so is the transfer they receive. Thus, domestic producers receive the largest portion of the incremental rents. The estimated efficiency gain ranges from $\$ 1931.4$ million to $\$ 5985.6$ million.

When the domestic distortion is relatively small, in cases (5) and (6), the sign of the welfare effect is reversed. On balance, the loss to consumers outweighs the gain to producers. Foreign firms capture the largest share of transfers to producers, and there is an overall loss of efficiency which ranges from $\$ 5.3$ million to $\$ 29.7$ milion. These effects resemble what we referred to in Section III as the standard textbook case.

The unusual welfare effects in cases (1) through (4) provide a graphic illustration of the theory of the second best: when distortions in the market for domestic steel are severe relative to distortions in the market for imports, it is possible to reduce the deadweight loss by adding distortions on the import side. Having mentioned this possibility compels us to close on a cautionary note. If antidumping action can be welfare-improving because of distortions in domestic markets, first-best policies addressed at those domestic distortions are still to be preferred. In our case, promoting competition can alleviate the domestic distortion without causing any loss on the import side.

Although we have attempted to extend simple welfare calculations in a number of directions, our model ultimately remains partial equilibrium. We have already seen how effects that are usually dismissed as second-order can be cru- 
cially important in an imperfectly competitive setting. Among the effects we have suppressed are distortions in factor markets, changes in the extent of collusion, dangers of foreign retaliation, and rent-seeking by domestic factors of production; this last possibility, for example, greatly diminishes the likelihood that the additional distortion will enhance welfare. Many of these extensions are readily incorporated into our framework. Even without these complications, however, our analysis suggests that governments must be able to estimate a relatively large number of parameters with considerable accuracy before they can be assured that this form of intervention is welfare-improving.

\section{v. Concluding Remarks}

In this paper, we have analyzed dumping and U.S. antidumping policy from a number of different perspectives. While attempting to address a broad range of questions in a relatively few pages, we recognize that each of these issues warrants more extensive treatment. The first sections of the paper analyze the evolution of U.S. antidumping policy and the design of the Trigger Price Mechanism. To understand the evolution of antidunping policy, we have argued, it is necessary to analyze how policy is adapted in response to political pressures; the TPM provides a dramatic illustration of these considerations. From the point of view of its architects, who felt pressure from all sides, the TPl was a political masterpiece. Economically, it was perhaps less masterful; its exponents may have incompletely anticipated how administered protection could distort established patterns of trade and production. An analysis of the TPM demonstrates also how administrative decisions on seemingly minor points such as the exchange rate to use in computing costs - can have major economic effects.

The latter sections of the paper use theoretical models to explain the 
sources of dumping and to illustrate the magnitude of its effects. The models of most relevance to the practices currently at issue in the steel industry seem to us models of oligopolistic rivalry in imperfectly competitive, segmented markets. Basing our analysis on the traditional economic definition of dumping as price discrimination in international trade, we have attempted to identify a number of crucial variables upon which the incidence of dumping will depend: the number of firms producing for each national market, their costs, their market shares, and the extent to which they recognize and exploit their mutual dependence. Finally, we have used these models of imperfect competition to illustrate how the size of the dumping ratio and the incidence of the TPM depend on certain crucial parameter values. Much remains to be done to establish the generality of our framework, but we hope at least that we have stimulated some of our readers to think along these lines. 


\section{Footnotes}

1. In this paper we are concerned solely with dumping and U.S. antidumping policies. We do not discuss countervailing duties imposed in response to foreign government subsidization of exports. However, see footnote 25 below.

2. Antidumping measures also were included in the Revenue Act of 1916, whose provisions unfortunately proved difficult to administer.

3. U.S. Senate (1934) discusses the origins of the Act.

4. The immediate impetus for the change was a complaint that Canadian sulfur was being sold in both U.S. and Canadian markets at prices below costs. The 1974 Act also authorized the Treasury to base constructed value calculations on data for comparable market economies when production costs in state-controlled economies proved difficult to measure.

5. See for example Crandall (1978, 1980), U.S. GAO (1979), and Kawahi to (1981).

6. Section 206(a) of the Trade Act of 1974 defined constructed value as the sum of (1) "The cost of materials...and of fabrication or other processing ...at a time preceding the date of exportation of the merchandise under consideration which would ordinarily permit the production of that particular merchandise in the ordinary course of business." (2) "An amount for general expenses...not less than ten per cent of material and of fabrication costs." (3) "An amount for profit not less than eight per cent of the sum of material and fabrication costs and general expenses." (4) "The cost of all containers and coverings...and all other expenses incidental to placing the merchandise ...in condition...ready for shipment to the U.S."

7. The debate over VRAs is recounted by Takacs (1976), Mueller and Kawahito 
(1979), and Adams and Dirlam (1980).

8. In the words of $i$ ts architects, the system was to "expedite relief from unfair import competition, but to do so in a manner which would not preclude competition in the U.S. market." See Solomon (1977), p. 8.

9. Treasury must acquire sufficient information upon which to base a determination within 75 days, and the complaintant must waive his right to verify the exporter's submission. In a related action, responsibility for enforcing U.S. antidumping statutes was transferred from Treasury to Commerce.

10. In practice, the constructed value provisions do not appear to have been invoked on these grounds.

11. American Importers Association (1979), p.21; Sato and Hodin (1982), p. 37.

12. U.S. Department of Commerce (1980), p. 5 .

13. Treasury News (July 20, 1980), p. 3.

14. Ibid. If the yield ratio is 80 per cent, the other 20 per cent is scrap. A credit in the amount of the value of the scrap was applied to production cost estimates for finished steel. The jield credit was raised in $19781 \mathrm{~V}$ on the grounds that Japanese scrap was actually a higher valued secondary material.

15. U.S. Department of Commerce (1980), p. 4.

16. We neglect feedback from trigger prices to exchange rates, and from there to domestic costs. The assumption that such feedback was negligible is crucial to our interpretation of Table 2. On these effects, see Eichengreen (1981, 1983).

17. Steel Tripartite Committee (1979), p. 8.

18. Mueller (1980), p. 1. 
19. Dirlam and Mueller (1981), p. 13.

20. McCormack (1981), p. 313. See also American Iron and Steel Institute (1978).

21. See Treasury News (April 13, 1978).

22. For a recent analysis, see U.S. General Accounting Office (1980), chapter 3, and U.S. GAO (1981), chapter 3. Similar points were made some years ago by Jondrow et al. (1976).

23. U.S. GAO (1980), p. 21. See Dirlam and Mueller (1981) and Walter (1982) for discussions of these allegations.

24. See United States versus Mitsui (1982).

25. See for example Caves and Jones (1973), pp.212-214, or Cordon (1974), pp.235-247.

26. This is not to imply that there is no role for policy toward industries facing import competition. For analyses of the arguments for adjustment assistance, see Bhagwati (1982).

27. It would be straightforward to introduce production and export subsidies at this point. However, as noted above, we feel that the subsidy question is logically distinct from the issues analyzed here, so we make no attempt to incorporate it into our model. For a similar approach to analyzing subsidies, see Brander and Spencer (1982). It would also be straightforward to introduce transport costs. Although we do not treat such costs explicitly, they can be thought of as a component of $c$. See also Brander (1981) and Brander and Krugman (1981).

28. See Rader (1972), Dansby and Willig (1979) and, for an elegant application to the Japanese steel industry, Yamawaki (1982). 
29. In other words, we assume $\sum_{i=1}^{k} \frac{d x_{i}}{d y_{q}}=\sum_{q \neq r}^{s} \frac{d y_{r}}{d y_{q}}$ for $a l l i, q$, and $r$. Dixit and Stern (1982) argue that this assumption captures the case where oligopolists are in the industry on broady equal terms.

30. If the oligopolists take fringe firms' reactions into account, then we get the standard Herfindahl Index in place of the truncated index. The conjectural variation is the firm's estimate of the slope of rivals' reaction functions. It can be heuristically interpreted as the perceived probability of retaliation. Thus, $\delta=0$ is the Cournot case, and $\delta=1$ is the case where each firm believes that other firms will try to preserve market shares. Cases of $\delta<0$, while conceivable, are not considered here. Firms' conjectures are taken as constant throughout. Modeling conjectures as rational makes it difficult to characterize industry equilibrium, so we follow standard practice by taking conjectural variations as exogenous. On rational conjectural variations, see citations in Kamien and Schwartz (1981).

31. Such tests of the "law of one price" are surveyed by Crouhy-Veyrac, Crouhy, and Melitz (1982).

32. Were national outputs perfect substitutes and market imperfections absent, one could visualize a scenario in which U.S. antidumping policy administered under the TPM caused European steel formerly destined for the U.S. to be diverted to Japanese markets or to remain in Europe and a corresponding quantity of Japanese production to be diverted to the U.S. In fact, allegations of this type of activity on part of European and Japanese producers have recently been made by the U.S. industry. Neglecting transport costs, in this case U.S. antidumping policies would 
have no efficiency or distributional effects. When steel products produced in different countries are imperfect substitutes, the analysis is more complicated but the implication is the same.

33. Mueller and Kawahito (1978) review the available evidence and present estimates of their own. For example, for 1976 their estimate of the ratio of European to U.S. costs is 1.17 . In this paper we present no evidence on the constancy of variable cost. Since Takacs (1976) finds marginal costs to be slightly declining, while others such as Crandall (1981) treat them as rising, this seems to be a judicious compromise. Our estimates of $\hat{c}^{*}$ for 1979 are constructed by adjusting Mueller and Kawahito's figure of $\$ 205$ in 1976 for the change in prices of industrial goods. We think of these figures as including costs of variable labor, coal, fuel oil, natural gas, electricity, iron ore and scrap, plus transportation and related expenses. For a number of reasons, including the fact that their calculations exclude the U.K., there is reason to treat $\$ 230$ as a lower bound; we use $\$ 290$ as an upper bound. We recognize, however that we have suppressed the large cost differentials that exist among producers in a given location. 
$\underline{\text { References }}$

Adans, Walter and Dirlam, Joel B., 1980. Unfair Competition in International Trade. In Adams, Walter et al., Tariffs, Quotas, and Trade: The Politics of Protectionism. San Francisco, Institute for Contemporary Studies.

American Importers Association, 1979. Analysis of Trade Agreements Act of 1979. New York: American Importers Association.

American Iron and Steel Institute, 1978. Annual Report. Washington, D.C.: AISI.

Bhagwati, J.N., ed., 1982. Import Competition and Response. Chicago: University of Chicago Press.

Brander, James, 1981. Intra-Industry Trade in Identical Commodities. Journal of International Economics 11: 1-14.

Brander, James and Krugman, Paul, 1981. A "Reciprocal Dumping" Model of International Trade. Paper read at the International Economics Seminar, Harvard University. Mimeographed.

Brander, James and Spencer, Barbara, 1982. Export Subsidies and International Market Share Rivalry. Paper presented to the NBER International Studies Program. Mimeographed.

Caves, Richard and Jones, Ronald, 1973. World Trade and Payments. Boston: Little Brown.

Corden, W.M., 1974. Trade Policy and Economic Welfare. Oxford: Clarendon Press.

Crandall, Robert W., 1978. Competition and "Dumping" in the U.S. Steel Market. Challenge 21: 13-20.

, 1980. Steel Imports: Dumping or Competition? 
Regulation 4: 17-24.

, 1981. The U.S. Steel Industry in Recurrent Crisis.

Washington, D.C.: The Brookings Institution.

Crouhy-Veyrac, L., Crouhy, M. and Melitz, J., 1982. More About the Law of One

Price. European Economic Review 18: 325-344.

Dansby, R.E. and Willig, R.D., 1979. Industry Performance Gradient Indexes.

American Economic Review 69: 249-260.

Davies, S.W. and McGuinness, A.J., 1982. Dumping at Less than Marginal

Cost. Journal of International Economics 12: 169-182.

Dirlam, Joel B. and Mueller, Hans, 1981. Import Restraints and Reindustrial-

ization: The Case of the U.S. Steel Industry. Middle Tennessee State

University Business and Economic Research Center Conference Paper No. 67.

Dixit, A. and Stern, N., 1982. Oligopoly and Welfare: A Unified Presentation

with Applications to Trade and Development. European Economic Review

19: $123-145$.

Eichengreen, Barry J., 1981. A Dynamic Model of Tariffs, Output and Employment

Under Flexible Exchange Rates. Journal of International Econorics 11:

$341-359$.

, 1982. The Simple Analytics of Dumping. Harvard

Institute of Economic Research Discussion Paper No. 943. , 1983. Effective Protection and Exchange Rate

Determination. Journal of International Money and Finance 2 .

Ethier, Wilfred, 1982. Dumping. Journal of Political Economy 90: 487-506.

Haberler, Gottfried, 1937. The Theory of International Trade with

Its Application to Commercial Policy. New York: Macmillan.

Harberger, Arnold C., 1974. Taxation, Resource Allocation, and Welfare. In 
Harberger, A.C., Taxation and Welfare. Boston: Little, Brown. Jondrow, James et al., 1976. Forms of Competition in the Steel Industry. Arlington, Virginia: Public Research Institute. Kamien, M.I. and Schwartz, N.L., 1981. Conjectural Variations. Northwestern University Center for Mathematical Studies in Economica and Management Science Discussion Paper No. 466S.

Kawahito, Kiyoshi, 1981. Economic Implications of U.S. Antidumping Statutes, With Special Reference to the Steel Trade. Middle Tennessee State University Business and Economic Research Center Conference Paper No. 63. Kravis, I.B., and Lipsey, R.E., 1977. Export Prices and the Transmission of Inflation. American Economic Review Papers and Proceedings 67: 155-163. Krugman, Paul, 1982. Import Protection as Export Promotion: International

Competition in the Presence of Oligopoly and Economies of Scale.

Massachusetts Institute of Technology. Mimeographed. McCormack, Garry P., 1981. The Reinstated Steel Trigger Price Mechanism: Reinforced Barrier to Import Competition. Fordham International Law Journal 4: 289-339.

Mueller, H., 1980. The Competitiveness of the. U.S. Steel Industry After the New Trigger Price Mechanism. Middle Tennessee State University Business and Economic Research Center Monograph No. 25. Mueller, H., and Kawahito, K., 1978. Steel Industry Economics. New York: Japan Steel Information Center. , 1979. Legal and Economic Aspects of the

Steel Import Issue. Middle Tennessee State University Business and Economic Research Center Conference Paper No. 42. Rader, Trout, 1972. Theory of Microeconomics. New York: Academic Press. 
Sato, Hideo, and Hodin, M.W., 1982. The U.S.-Japanese Steel Industry Issue of 1977. In Destler, I.M. and Sato, H., eds. Coping with U.S.-Japanese Economic Conflicts. Lexington, Massachusetts: Heath.

Solomon, Anthony M., 1977. Report to the President: A Comprehensive

Program for the Steel Industry. Mimeographed.

Spence, A.M., 1981. The Learning Curve and Competition. Bell Journal of

Ec onomics 12: 49-70.

Steel Tripartite Committee, 1979. Steel Trigger Price Mechanism. A One Year

Review for the Steel Tripartite Committee. June 25, Washington, D.C.

Mimeographed.

Stegemann, Klaus, 1980. The Efficiency Rationale of Antidumping Policy and

Other Measures of Contingency Protection. Queen's University Institute for

Economic Research Discussion Paper No. 387.

Stone, J.A., 1979. Price Elasticities of Demand for Imports and Exports:

Industry Estimates for the U.S., the E.E.C. and Japan. Review of

Economics and Statistics 59: 306-312.

Takacs, Wendy E., 1976. Quantitative Restrictions on International Trade.

Ph.D. Dissertation, Johns Hopkins University •

- 1982. Cyclical Dumping of Steel Products: Comment. Journal

of International Economics 12: 381-384.

Tarr, David G., 1979. Cyclical Dumping: The Case of Steel Products. Journal of International Economics 9: 57-63.

, 1982a. Estimation of the Costs to the U.S. Economy and to

Consumers of the Imposition of Countervailing Duties on the Steel Products

Under Investigation at the Departnent of Commerce. Mimeographed.

, 1982b. Cyclical Dumping of Steel Products: Another Look. 
Journal of International Economics 12: 377-380.

United States Department of Commerce, International Trade Administration, 1978-79. Announcement of Trigger Price Levels, various issues, Washington, D.C.

, 1980. Reinstatement Notice. 45 F.R. 66833, ret. 8 . , 1981. Steel Trigger Price Mechanism Procedures Manual.

46 F.R. 22738, April 20.

United States General Accounting Office, 1979. Report to the Congress: U.S. Administration of the Antidumping Act of 1921. ID915. Washington, D.C.: GPO. - 1980. Report to the Congress: Administration of the Steel Trigger Price Mechanism, ID8015. Mimeographed. , 1981. Report to the Congress: New Strategy Required for

Aiding Distressed Steel Industry. EMDB129. Washington, D.C.: GPO. United States Senate, 1934. Antidumping Legislation and Other Import

Regulation in the United States and Foreign Countries. S.Doc. 112, 73 rd Congress, 2nd Session.

United States Versus Mitsui, et 1 l., 1982. Brief. Filed 7/20/82 with the

United States District Court for the Northern District of California. Viner, Jacob, 1923. Dumping: A Problem in International Trade. Chicago: University of Chicago Press.

Walter, Ingo, 1982. "Structural Adjustment and Trade Policy in the International Steel Industry." Institut fur Volkswirtschaftslehre und statistik der Universitat Mannheim Discussion Paper No. 220/82.

Yamawaki, Hideki, 1982. Market Structure, Capacity Expansion and Pricing.

Ph.D. Dissertation, Harvard University • 